\title{
Genetic Polymorphisms of the Coding Region (Exon 6) of Calpastatin in Indonesian Sheep
}

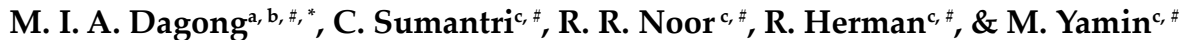 \\ aAnimal Production and Technology Study Program, Postgraduate School, Bogor Agricultural University \\ ${ }^{\mathrm{b}}$ Animal Science Faculty, Hasanuddin University \\ Jln. Perintis Kemerdekaan KM 10 Tamalanrea, Makassar 90245, Indonesia \\ 'Department of Animal Production and Technology, Animal Science Faculty, Bogor Agricultural University \\ \#Jln. Agatis, Kampus IPB Darmaga, Bogor 16680, Indonesia \\ (Received 31-01-2011; accepted 09-05-2011)
}

\begin{abstract}
ABSTRAK
Kalpastatin (CAST) berperan dalam menghambat fungsi enzim kalpain yang terlibat dalam mengatur turn over protein dan pertumbuhan. Tujuan penelitian ini adalah untuk mengidentifikasi keragaman genetik gen CAST khususnya pada seluruh daerah ekson 6 pada domba lokal. Metode PCRSSCP digunakan untuk mengidentifikasi variasi pada gen CAST. Sebanyak 258 ekor domba lokal dari 8 subpopulasi digunakan dalam penelitian ini, tiga group berasal dari Domba Ekor Tipis (DET) dari Sukabumi, UP3J Jonggol dan Kissar, sedangkan sisanya antara lain domba Priangan dari Margawati dan Wanaraja serta Domba Ekor Gemuk (DEG) dari Donggala, Sumbawa, dan pulau Rote. Analisis SSCP menunjukkan tiga pola SSCP berbeda yang merujuk pada tiga alel berbeda pada lokus CAST yaitu alel CAST-1, 2 dan 3 dengan lima genotipe berbeda. Variasi genetik di antara populasi dihitung berdasarkan frekuensi alel dan genotipenya. Sebagian besar populasi yang diteliti menunjukkan polimorfisme gen CAST dengan frekuensi masing-masing genotipe CAST-11, CAST-12, CAST-22, CAST-32, dan CAST33 adalah $0.286,0.395,0.263,0.046$, dan 0.007 . Alel CAST-1 dan 2 adalah alel yang paling umum pada seluruh populasi dengan total frekuensi 0.970 , sementara alel yang langka adalah CAST-3 (0.030) dan hanya ditemukan di populasi DET. Kesimpulan yang dihasilkan adalah bahwa gen CAST pada domba lokal bersifat polimorfik dan informasi keragaman tersebut dapat digunakan untuk mencari hubungan dengan sifat pertumbuhan, kualitas karkas dan daging.
\end{abstract}

Kata kunci: domba lokal, kalpastatin, PCR-SSCP, exon 6

\begin{abstract}
Calpastatin (CAST) is an indigenous inhibitor of calpain that involved in regulation of protein turn over and growth. The objective of this research was to identify genetic polymorphisms in the entire exon 6 of calpastatin gene in Indonesian local sheep. A PCR-SSCP method was carried out to identify genetic variation of CAST gene. In total 258 heads of local sheep from 8 populations were investigated, three groups of samples were Thin Tail Sheep (TTS) from Sukabumi, Jonggol, and Kissar. The rest samples were Priangan sheep (PS) from Margawati (Garut meat type) and Wanaraja (Garut fighting type) and Fat Tail Sheep (FTS) from Donggala, Sumbawa, and Rote islands. SSCP analysis revealed that three different SSCP patterns corresponded to three different alleles in the CAST locus (CAST-1, 2 , and 3 allele) with five different genotypes. Genetic variation between local sheep populations were calculated based on genotypic and allelic frequencies. Most populations studied were polymorphic, with genotype frequencies of CAST-11, CAST-12, CAST-22, CAST-32, and CAST-33 were 0.286, 0.395, $0.263,0.046$, and 0.007 respectively. CAST-1 and 2 alleles were most commonly found in all populations with total frequency was 0.970 , while CAST-3 was a rare allele 0.030 and only found in TTS population. Variation in the CAST gene could be used for the next research as genetic diversity study or to find any association between CAST polymorphism with birth weight, growth trait and carcass quality in Indonesian local sheep.
\end{abstract}

Key words: Indonesian local sheep, calpastatin, PCR-SSCP, exon 6

* Corresponding author:

Phone : +62-0411-587217, e-mail: iccangdagong@yahoo.com 


\section{INTRODUCTION}

Calpastatin (CAST) is a member of calpain calpastatin system involving three molecules, $\mu$-calpain, $\mathrm{m}$-calpain and calpastatin as specific inhibitor of the two calpain. This system implicated in various physiological and pathological processes (Kidd et al., 2000; Huang et al., 2001; Goll et al., 2003; Raynaud et al., 2004) and involved in regulation of protein turn over and growth (Goll et al., 1992), myoblast migration (Dedieu et al., 2003) and fusion (Temm-Grove et al., 1999). CAST is therefore believed to be an excellent candidate gene for growth and carcass trait in livestocks.

Many studies have demonstrated the association of CAST polymorphism with carcass and meat quality, especially tenderness in several livestocks (Schenkel et al., 2006; Casas et al., 2006; Curi et al., 2009). In the sheep, the polymorphism of CAST gene was reported to have significant association with birth weight (Byun et al., 2008), and body weight (Sumantri et al., 2008,) but did not influence lamb tenderness (Zhou et al., 2008a).

Previous study reported the polymorphisms of CAST in Indonesian local sheep but this study only concentrated in intron region (Sumantri et al., 2008), and no investigation yet reported in coding sequences of local sheep. Exon 6 was the largest exon in the ovine calpastatin, and known to be polymorphic in the sheep with five different alleles (Zhou et al., 2007; Byun et al., 2009a). Previous study has shown that sequences coded by exon 6 , contained multiple phosporylation sites, and directly involved in determining the cell localization of calpastatin (Tullio et al., 2009). This study suggested that variation in these sequences may impact on the activity of $\mathrm{Ca}^{2+}$ channels and hence regulate or modulate calpain activity. The objectives of this research were to identify polymorphism of CAST gene in the coding region (Exon 6) in Indonesian local sheep population.

\section{MATERIALS AND METHODS}

\section{Blood Samples and DNA Extraction}

In total 258 sheep from 8 populations were investigated, i.e. (i) Thin Tail Sheep (TTS) from Sukabumi (50), Jonggol (26), and Kissar (32); (ii) Priangan sheep (PS) from Wanaraja (Garut fighting type) (35), Margawati (Garut meat type) (20); and (iii) Fat Tail Sheep (FTS) from Sumbawa (29), Donggala (54), and Rote (12). DNA extraction was carried out by using standar phenol chloroform method (Sambrook et al., 1989) with some modification by Andreas et al. (2010).

\section{PCR Amplification}

A pair of PCR primer, forward: 5'-GTTATGA ATTGCTTTCTACTC- $3^{\prime}$ and reverse: 5'-ATACGATT GAGAGACTTCAC- $3^{\prime}$ was designed to amplify part of intron 5 and whole exon 6 of CAST gene, as described by Zhou et al. (2007). PCR amplification was carried out in $25 \mu \mathrm{l}$ reaction containing 50-100 ng genomic DNA, 0.25 $\mu \mathrm{M}$ of each primer, $200 \mu \mathrm{M}$ dNTPs (Fermentas), $4.0 \mu \mathrm{M}$
$\mathrm{Mg}^{2+}, 0.5 \mathrm{U}$ of Toptaq DNA polymerase (Qiagen, Hilden, Germany), and 1x the reaction buffer. The condition of thermal cycling consisted of pradenaturation at 95 ${ }^{\circ} \mathrm{C}$ for $5 \mathrm{~min}$, followed by 35 cycles of denaturation 95 ${ }^{\circ} \mathrm{C}$ for $30 \mathrm{~s}$, annealing $56{ }^{\circ} \mathrm{C}$ for $45 \mathrm{~s}$, and extension 72 ${ }^{\circ} \mathrm{C}$ for $45 \mathrm{~s}$. The final extension step was at $72{ }^{\circ} \mathrm{C}$ for 5 min. Amplification was carried out in a thermal cycler (Mastercycler Personal 22331, Eppendorf, Germany). The PCR amplicon were checked on $1.5 \%$ agarose gels in 0.5 x TBE buffer containing $10 \%$ of ethidium bromide at 100 volt for $45 \mathrm{~min}$ and visualized by UV transiluminator.

\section{Single Strand Conformational Polimorphism (SSCP) Analysis}

A SSCP procedure was used to identify variation in the amplicon of CAST locus. A $5 \mu \mathrm{l}$ aliquot of each amplimer was mixed with $5 \mu$ l of loading dye $(98 \%$ formamide, $10 \mathrm{mM}$ EDTA, $0.025 \%$ bromophenol blue, $0.025 \%$ xylene cyanol). After denaturation at $95{ }^{\circ} \mathrm{C}$ for 5 min, samples were rapidly cooled on ice bath and then loaded on $12 \%$ acrylamide : bisacrylamide $(29: 1)$ gels. Electrophoresis was performed by using Protean II xi cells (Bio-Rad), at $300 \mathrm{~V}$ for $18 \mathrm{~h}$ at refrigerator condition in $0.5 \times$ TBE buffer. Gels were silver stained based on the method of Byun et al. (2009b) with modification in staining solution $\left(0.1 \% \mathrm{AgNO}_{3^{\prime}} 0.04 \% \mathrm{NaOH} 10 \mathrm{~N}\right.$, and $0.4 \% \mathrm{NH}_{3}$ ).

\section{DNA Sequencing and Analysis}

Amplicon that produced SSCP patterns that could be confirmed as homozygous were used directly as templates for DNA sequencing. Prior to sequencing, one of the unique bands representing each allele was cut out of the polyacrylamide gel (PAGE) and purified by the method as described by Hu et al. (2010). This was then used as the DNA template for reamplification and sequencing. To ensure these templates were similar to original sequences and not the result of amplification error, the identity of the templates cut from PAGE was confirmed by matching the PCR SSCP patterns generated from the templates and the corresponding genomic DNA. Sequence alignments, translations and comparisons were carried out using MEGA software version 4.0 (Tamura et al., 2008). The BLAST (basic local alignment search tool) program was used to search the NCBI GenBank (http://www.ncbi.nlm.nih.gov/BLAST) databases for homologous sequences.

\section{Statistical Analysis}

The genotype and allele frequencies were calculated based on Nei \& Kumar (2000) formulation.

$$
\begin{aligned}
& \mathrm{X}_{\mathrm{ii}}=\frac{\mathrm{n}_{\mathrm{ii}}}{\mathrm{N}} \times 100 \% \\
& \mathrm{X}_{\mathrm{i}}=\frac{\left(2 \mathrm{n}_{\mathrm{ii}}+\sum_{\mathrm{j} \neq \mathrm{i}} \mathrm{n}_{\mathrm{ij}}\right)}{2 \mathrm{~N}}
\end{aligned}
$$


where $X i=\mathrm{ii}^{\text {th }}$ genotype frequency, $X_{i}=\mathrm{i}^{\text {th }}$ allele frequency, $n_{i i}=$ number of sample of ii genotype, $n_{i j}=$ number of sample of ij genotype, and $N=$ total sample.

Test of Hardy-Weinberg equilibrium (HWE) with chi-square test (Kaps \& Lamberson, 2004).

$$
X^{2}=\sum(\text { Obs }-\operatorname{Exp})^{2} / \operatorname{Exp}
$$

where $\chi^{2}=$ chi-square, $O b s=$ number of observation of $\mathrm{ii}^{\text {th }}$ genotype, and $E x p=$ number of expected of $\mathrm{ii}^{\text {th }}$ genotype.

Observed $\left(H_{o}\right)$ and Expected heterozygosity $\left(H_{e}\right)$ based on Nei's heterozygocities (1973) and computed using PopGene32 software version 1.31 (Yeh et al., 1999).

$$
\begin{aligned}
& H_{o}=\sum_{k}^{s} w_{k} \sum_{i=j}^{q} X_{k i j} \\
& H_{a}=1-\sum_{k}^{s} w_{k} \sum_{i}^{q} x_{k i}^{2}
\end{aligned}
$$

where $H_{o}=$ observed within-population heterozygocity, $H_{e}=$ expected within-population heterozygocity, $\mathrm{w}_{\mathrm{k}}=$ relative population size, $X_{k i j}(i \neq j)=$ the frequency of $A_{i} A_{i}$ in the $\mathrm{k}^{\text {th }}$ population.

\section{RESULTS AND DISCUSSION}

\section{PCR-SSCP Analysis of CAST Gene}

Part of intron 5 and entire exon 6 of CAST gene were amplified by PCR using forward and reverse primer, with predicted amplicons 254 bp in length (Figure 1). PCR-SSCP analysis showed polymorphism in this region with three unique SSCP banding patterns. Three unique banding patterns corresponding to three different alleles, CAST-1, CAST-2, and CAST-3 allele. Either one or two unique banding patterns were found in each individual sample that consistent with either homozygous or heterozygous with five different genotypes, CAST-11, CAST-12, CAST-22, CAST-32, and CAST-33. The CAST-31 genotype was not observed in this study. Figure 2 shows the electrophoresis of CAST genotypes after SSCP.

The level of polymorphisms that found in this study was lower than reported by Zhou et al. (2007) with five different allelic in Merino, Corriedale, Poll Dorset and NZ crossbreed sheep. However, it was higher than previously reported in Indonesian local sheep (using PCR-RFLP; Sumantri et al., 2008), Iranian Karakul sheep (Shahroudi et al., 2006), and Kurdi sheep (Nassiry et al., 2006).

\section{Genetic Diversity of CAST Gene}

The results of this study may indicate that the CAST gene in the local sheep is polymorphic in all populations. Genotype frequency and allele frequency of the CAST gene is presented in Table 1 . The study observed only three alleles (CAST-1, 2 and 3) and five genotypes (CAST-11, 12, 22, 32, and 33) in Indonesian local sheep populations, but not genotype of CAST-31. The most frequent alleles were CAST- 1 and CAST-2 that contribute $48.4 \%$ for each allele and both counted $97 \%$, while CAST-3 was rare allele $(3 \%)$. The most frequent genotype was CAST-12 (39.5\%). Zhou et al. (2007) also found that CAST-1 and CAST-2 were most common alleles, and both counted for $82 \%$ of the allele population in Merino, Corriedale, Romney, Poll Dorset and NZ cross-breed, while the rare allele were CAST-3 (13\%), CAST-4 (2\%), and CAST-5 (3\%).

CAST-11 genotype frequencies in FTS group from Sumbawa, Rote, and Donggala population ranged from 0.08 to 0.166 . Those values were lower than the PS group from Margawati (0.850) or TTS group from Jonggol (0.423) population. CAST-12 genotype frequencies in FTS group with the range of $0.103-0.833$ was higher than PS group from Wanaraja (0.571) and TTS group from Kissar (0.531) population. While the CAST-22 frequencies in FTS with the range of $0.083-0.351$ were higher than MTS and TTS group. CAST-32 genotype only found in TTS group (Sukabumi, Kissar, and Jonggol), with the highest frequencies in Kissar population (0.156). Frequency of CAST-33 genotype was 0.040 and only found in Sukabumi population.

Genotype and allele frequency differences in populations studies demonstrated the high diversity of local sheep. Local sheep population in Indonesia has CAST-1 and 2 alleles in the same frequency (48.4\%) and spread throughout population, while the CAST-3 was rare

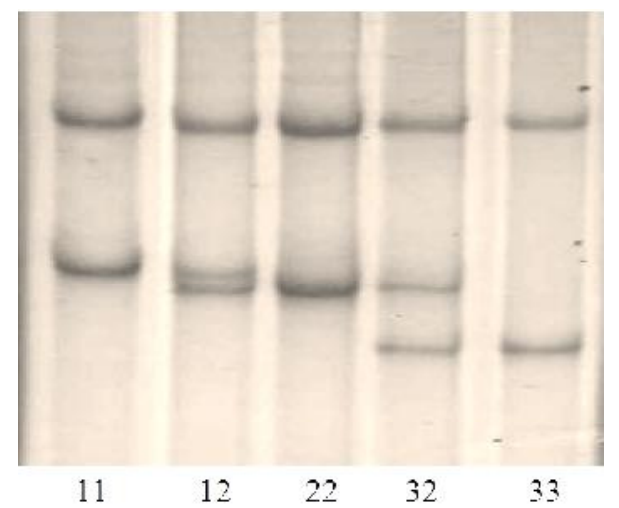

Figure 2. PCR-SSCP (single strand conformational polymorphism) of the ovine CAST gene 
allele and only found in the thin tail sheep population (Sukabumi, Jonggol, and Kissar).

Another study using PCR-RFLP reported the polymorphisms of calpastatin (CAST-Msp1 locus) in Indonesian local sheep. With two types of alleles ( $\mathrm{M}$ and $\mathrm{N}$ ), but only found two types of genotypes (MN and NN) with the frequency of $25 \%$ and $75 \%$ for $\mathrm{MN}$ and NN genotypes, and $13 \%$ and $87 \%$ for $\mathrm{M}$ and $\mathrm{N}$ alleles (Sumantri et al., 2008).
The result of chi-square $\left(X^{2}\right)$ test showed the distribution of six genotypes in the population were not in Hardy-Weinberg Equilibrium (Tabel 2). CAST-31 genotype was not found, probably due to a non-random mating system or because of direct selection (Bourdon, 2000). According to Nei \& Kumar (2000), genetic diversity can be measured by using heterozygosity value. Observed heterozygosity $(44.2 \%)$, expected heterozygosity $(53.0 \%)$, Nei's expected heterozygosity (52.9\%),

Tabel 1. Genotype and allele frequency of CAST gene in Indonesian local sheep

\begin{tabular}{|c|c|c|c|c|c|c|c|c|c|c|}
\hline \multirow{2}{*}{ Population } & \multirow{2}{*}{$\mathrm{N}$} & \multicolumn{5}{|c|}{ CAST Genotype } & \multirow[b]{2}{*}{33} & \multicolumn{3}{|c|}{ CAST Allele } \\
\hline & & 11 & 12 & 22 & 31 & 32 & & 1 & 2 & 3 \\
\hline Donggala (FTS) & 54 & 0.166 & 0.481 & 0.351 & 0.00 & 0.00 & 0.00 & 0.407 & 0.592 & 0.00 \\
\hline Sumbawa (FTS) & 29 & 0.103 & 0.103 & 0.793 & 0.00 & 0.00 & 0.00 & 0.155 & 0.844 & 0.00 \\
\hline Rote (FTS) & 12 & 0.083 & 0.833 & 0.083 & 0.00 & 0.00 & 0.00 & 0.500 & 0.500 & 0.00 \\
\hline Sukabumi (TTS) & 50 & 0.320 & 0.300 & 0.220 & 0.00 & 0.120 & 0.040 & 0.470 & 0.430 & 0.100 \\
\hline Kissar (TTS) & 32 & 0.281 & 0.531 & 0.031 & 0.00 & 0.156 & 0.00 & 0.546 & 0.375 & 0.078 \\
\hline Jonggol (TTS) & 26 & 0.423 & 0.346 & 0.192 & 0.00 & 0.038 & 0.00 & 0.596 & 0.384 & 0.019 \\
\hline Margawati (PS) & 20 & 0.850 & 0.100 & 0.050 & 0.00 & 0.00 & 0.00 & 0.900 & 0.100 & 0.00 \\
\hline Wanaraja (PS) & 35 & 0.228 & 0.571 & 0.200 & 0.00 & 0.00 & 0.00 & 0.514 & 0.485 & 0.00 \\
\hline Total & 258 & 0.286 & 0.395 & 0.263 & 0.00 & 0.046 & 0.007 & 0.484 & 0.484 & 0.030 \\
\hline
\end{tabular}

Note: $\mathrm{n}=$ individual number, FTS= Fat tail sheep, TTS= Thin tail sheep, and PS= Priangan sheep.

Tabel 2. Observed and expected genotype frequency of CAST gene in local sheep

\begin{tabular}{ccccc}
\hline Genotype & Observed freq. (O) & Expected freq. (E) & X2 (chi-square) & X2 tabel $(0.01 ; 3)$ \\
\hline CAST-11 & 74 & 60.43 & 30.55 & 11.345 \\
CAST-12 & 102 & 121.35 & \\
CAST-22 & 68 & 60.43 & \\
CAST-31 & 0 & 7.76 & \\
CAST-32 & 12 & 7.76 & \\
CAST-33 & 2 & 0.23 & \\
Total & 258 & 258 & \\
\hline
\end{tabular}

and average heterozygosity (44.5) value of CAST locus in Indonesian sheep were medium. Observed heterozygosity, expected heterozygosity, and Nei's expected heterozygosity value of CAST locus in each population are presented in Tabel 3.

\section{Sequences Analysis}

Sequence analysis revealed that amplicons varied from 253 to $254 \mathrm{bp}$ in length. These were the expected size based on previously reported by Zhou et al. (2007). All of the sequences identified were shared high similarity or identical to the published ovine and bovine CAST gene sequences (Figure 3). Based on homology of bovine CAST gene sequences with GenBank Accession Nos. EF443057 and AY834770 (Zhou et al., 2008c \& Raynaud et al., 2005), exon 6 was the largest exon of ovine CAST gene, with $114 \mathrm{bp}$ in length and coding around 38 amino acid residues.

Based on sequence analysis, it identified that three SSCP patterns represented three allelic sequences of ovine CAST, and identified four single nucleotide polymorphisms (SNPs). All of the nucleotide variation identified in this study was similar to that reported previously by Zhou et al. (2007). SNP position of CAST-1 allele were at $62 \mathrm{bp}(\mathrm{G}>\mathrm{A})$ position (GenBank acc. no. DQ414513) relative to the CAST-2 allele sequences (GenBank acc. no. DQ414514), and SNPs position of CAST-3 allele were at $65 \mathrm{bp}(\mathrm{G}>\mathrm{T}), 69 \mathrm{bp}$ (indelT) and $96 \mathrm{bp}(\mathrm{A}>\mathrm{T})$ position (GenBank acc. no. DQ414517) relative to the CAST-1 and CAST-2 sequences.

Mutation in CAST-3 allele in the exon 6 region at $96 \mathrm{bp}(\mathrm{A}>\mathrm{T})$ position was a non synonymous mutation which would induced Gln/Leu substitution (Figure 3), 
Tabel 3. Observed and expected heterozygosity value of CAST gene in Indonesian sheep

\begin{tabular}{lccccc}
\hline \multirow{2}{*}{ Population } & $\mathrm{N}$ & \multicolumn{3}{c}{ Heterozygosity } \\
\cline { 3 - 5 } & & Ho & He & Nei $^{*}$ & Average \\
\hline Donggala (FTS) & 54 & 0.481 & 0.487 & 0.482 & 0.262 \\
Sumbawa (FTS) & 29 & 0.103 & 0.266 & 0.500 & 0.584 \\
Rote (FTS) & 12 & 0.833 & 0.521 & 0.554 \\
Sukabumi (TTS) & 50 & 0.420 & 0.590 & 0.496 \\
Kissar (TTS) & 32 & 0.687 & 0.563 & 0.180 \\
Jonggol (TTS) & 26 & 0.384 & 0.506 & 0.499 \\
Margawati (PS) & 20 & 0.100 & 0.184 & 0.529 \\
Wanaraja (PS) & 35 & 0.571 & 0.506 & 0.445 \\
Total & 258 & 0.442 & 0.530 & 0 \\
\hline
\end{tabular}

Note: $\mathrm{n}=$ individual number, Ho= Observed heterozygosity, He= Expected heterozygosity according to Levene (1949) and Nei's (1973).

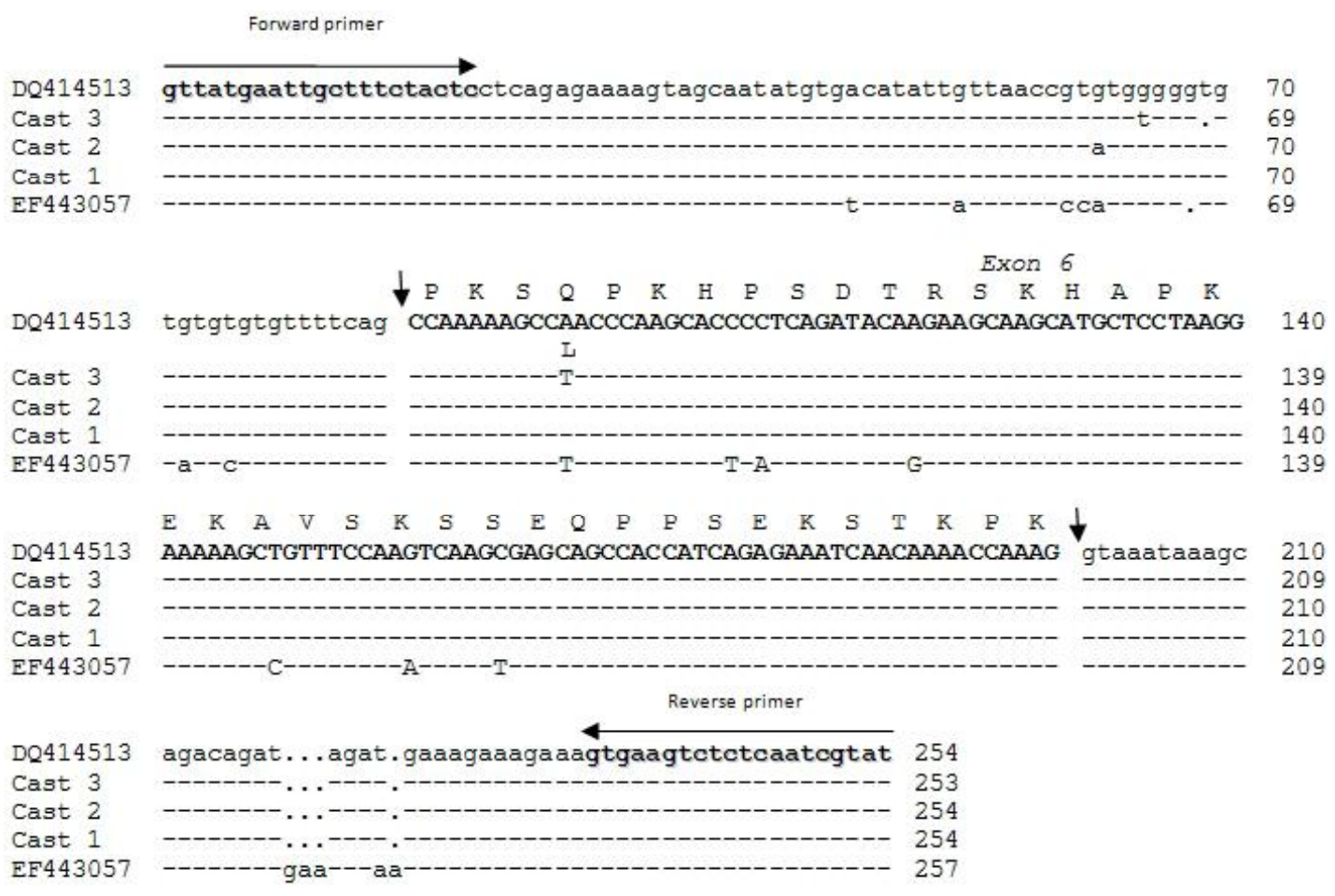

Figure 3. Nucleotide sequences of the ovine CAST-1, 2, and 3 allele and predicted amino acid sequences. DQ414513 and EF443057 were GenBank accession nos. of published ovine and bovine CAST sequences (Zhou et al., 2007 \& 2008c).

and it functional significance was unknown (Zhou et al., 2007). However, it has been suggested that calpastatin has a Ca2+ channel regulating function located in the $\mathrm{L}$ domain (Hao et al., 2000), and reported by Tullio et al. (2009) that sequences were coded by exon 6, containing multiple phosporylation sites, and directly involved in determining the cell localization of calpastatin. This suggests that variation in this sequences may impact on the activity of $\mathrm{Ca} 2+$ channels and hence regulate or modulate calpain activity. All variation in the intron region may affect RNA processing and consequently the function and level of expression of calpastatin (Zhou et al., 2007).
Byun et al. (2008) reported that allele A (CAST-1) and C (CAST-3) had a significant effect on birth weight, but did not significantly affect the growth rate to weaning, while allele B (CAST-2) did not significantly affect the birth weight and growth rate. All of these three alleles (CAST-1, 2, and 3) or genotypes variation in the CAST locus did not significantly affect lamb tenderness (Zhou et al., 2008a).

The polymorphism of CAST exon 6 in goat also reported by Zhou et al. (2008b), who identified a nonsynonymous amino acid variation in the caprine CAST which would result in a Ser/Arg amino acid change in the domain $\mathrm{L}$ of the protein. A synonymous SNP (T>C) 
mutation was also indentified in bovine CAST exon 6 sequences (Zhou et al., 2008c).

\section{CONCLUSION}

Calpastatin (CAST) in the intron 5-exon 6 regions show polymorphism in Indonesian local sheep. Five genotypes were observed in this study, i.e CAST-11, CAST-12, CAST-22, CAST-32, and CAST-33 with the genotype frequencies were $0.286,0.395,0.263,0.046$, and 0.007 respectively. CAST-1 and CAST-2 were the most common alleles with total frequency in population 0.970 , while the rarest allele was CAST-3 (0.030). Variation in the CAST gene could be used for the next research as genetic diversity study or to find any association between CAST polymorphism with birth weight, growth trait and carcass quality in Indonesian local sheep.

\section{ACKNOWLEDGEMENT}

The work was supported by Directorate General of Higher Education (DGHE), Ministry of National Education Republic of Indonesia through the Hibah Kompetensi 2010 project with contract no. 224/SP2H/ PP/DP2M/III/2010. We thank H. Bunyamin (Tawakkal Farm) and JASTRU (Jonggol Animal Science Teaching and Research Unit) of Animal Science Faculty, Bogor Agricultural University for blood samples and E. Andreas for technical assistance.

\section{REFFERENCES}

Andreas, E., C. Sumantri, H. Nuraini, A. Farahjallah, \& A. Anggraeni. 2010. Identification of GH/AluI and GHR/AluI genes polymorphisms in Indonesian buffalo. JITAA. 35 : $215-221$

Bourdon, R. M. 2000. Understanding Animal Breeding. $2^{\text {nd }}$ Ed. Prentice Hall Inc. Upper Saddle River, New Jersey.

Byun, S. O., H. Zhou, R. H. J. Forrest, C. M. Frampton, \& J. G. H. Hickford. 2008. Association of the ovine calpastatin gene with birth weight and growth rate to weaning. Anim. Genet. 39: 572-576.

Byun, S. O., H. Zhou, \& J. G. H. Hickford. 2009a. Haplotypic diversity within the ovine calpastatin (CAST) gene. Mol. Biotechnol. 41: 133-137.

Byun, S. O., Q. Fang, H. Zhou, \& J. G. H. Hickford. 2009b. An effective method for silver staining DNA in large numbers of polyacrylamide gels. Anal. Biochem. 385: 174-175.

Casas, E., S. N. White, T. L. Wheeler, S. D. Shackelford, M. Koohmaraie, D. G. Riley, C. C. Chase, D. D. Johnson, \& T. P. L Smith. 2006. Effects of calpastatin and mikro calpain markers in beef cattle on tenderness traits. J. Anim. Sci. 84: 520-525.

Curi, R. A., L. A. L. Chardulo, M. C. Mason, M. D. B. Arrigoni, A. C. Silveira, \& H. N. de Oliveira. 2009. Effect of single nucleotide polymorphism of CAPN1 and CAST genes on meat traits in Nellore beef cattle (Bos indicus) and their crosses with Bos taurus. Anim. Genet. 40: 456-462.

Dedieu, S., G. Mazeres, S. Poussard, J. J. Brustis, \& P. Cottin. 2003. Myoblast migration is prevented by a calpain-dependent accumulation of MARCKS. Biol. Cell. 95: 615-623.

Goll, D. E., V. F. Thompson, R. G. Taylor, \& J. A. Christiansen. 1992. Role of the calpain system in muscle growth. Biochimie. 74: 225-237.
Goll, D. E., V. F. Thompson, H. Li, W. Wei, \& J. Cong. 2003. The calpain system. Physiol. Rev. 83: 731-801.

Hao, L. Y., A. Kameyama, S. Kuroki, J. Takano, E. Takano, M. Maki, \& M. Kameyama. 2000. Calpastatin domain L is involved in the regulation of L-type $\mathrm{Ca}^{2+}$ channels in guinea pig cardiac myocytes. Biochem. Biophys. Res. Commun. 279: 756-61.

Huang, Y. \& K. K. W. Wang. 2001. The calpain family and human disease. Trends. Mol. Med. 7: 355-362.

Hu, J., H. Zhou, A. Smyth, Y. Luo \& J. G. H. Hickford. 2010. Polymorphism of the bovine ADBR3 gene. Mol. Biol. Rep. 37: 3389-3392.

Kaps, M. \& W. R. Lamberson. 2004. Biostatistics for Animal Science. CABI Publishing, London.

Kidd, V. J., J. M. Lahti, \& T. Teitz. 2000. Proteolytic regulation of apoptosis. Semin. Cell. Dev. Biol. 11: 191-201.

Nassiry, M. R., M. Tahmoorespour, A. Javadmanesh, M. Soltani, \& S. F. Far. 2006. Calpastatin polymorphism and its association with daily gain in Kurdi sheep. Iran J. Biotechnol. 4: 188-192.

Nei, M. 1973. Analysis of gene diversity in subdivided populations. PNAS. 70: 3321-3323.

Nei, M. \& S. Kumar. 2000. Molecular Evolutian and Phylogenetics. Oxford University Press, New York.

Raynaud, F., G. Carnac, A. Marcilhac, \& Y. Benyamin. 2004. mCalpain implication in cell cycle during muscle precursor cell activation. Exp. Cell. Res. 298: 48-57.

Raynaud, P., C. Jayat, M. P. Laforet, H. Leveziel \& V. Amarger. 2005. Four promoters direct expression of the calpastatin gene. Arch. Biochem. Biophys. 437: 69-77

Sambrook, J., E. F. Fritsch \& T. Maniatis. 1989. Molecular Cloning: A Laboratory Manual. $2^{\text {nd }}$ Ed. Cold Spring Harbor Laboratory Press, USA.

Schenkel, F. S., S. P. Miller, Z. Jiang, I. B. Mandel, X. Ye, H. Li, \& J. W. Hilton. 2006. Association of a single nucleotide polymorphism in the calpastatin gene with carcass and meat quality traits of beef cattle. J. Anim. Sci. 84: 291-299.

Shahroudi, F. E., M. R. Nassiry, R. Valizadeh, A. H. Moussavi, M. T. Pour \& H. Ghiasi. 2006. Genetic polymorphisms at MTNR1A, CAST and CAPN loci in Iranian Karakul sheep. Iran J. Biotechnol. 4: 117-122.

Sumantri, C., R. Diyono, A. Farajallah \& I. Inounu. 2008. Polymorphism of calpastatin gene and its effect on body weight of local sheeps. JITV. 13: 117-126.

Tamura, K., J. Dudley, M. Nei, \& S. Kumar. 2008. MEGA software (version 4) : Molecular Evolutionary Genetics Analysis. Center of Evolutionary Functional Genomics Biodesign Institute. Arizona State University.

Temm-Grove, C. J., D. Wert, V. F. Thompson, R. E. Allen, \& D. E. Goll. 1999. Microinjection of calpastatin inhibits fusion in myoblasts. Exp. Cell. Res. $247: 293-303$.

Tullio, R. D., C. Cantoni, C. Broggio, C. Prato, R. Stifanese, M. Averna, R. Antolini, S. Pontremoli, \& E. Melloni. 2009. Involvement of exon 6-mediated calpastatin intracellular movements in the modulation of calpain activation. Biochim. Biophys. Acta. 1790: 182-187.

Yeh, F. C., R. C. Yang, \& T. Boyle. 1999. POPGENE version 1.31: Microsoft Window-based Freeware for Population Genetic Analysis. University of Alberta Canada. Edmonton, AB.

Zhou, H., J. G. H Hickford, \& H. Gong. 2007. Polymorphism of the ovine calpastatin gene. Mol. Cell Probes. 21: 242-244.

Zhou, H., S. O. Byun, C. M. Frampton, R. Bickerstaffe, \& J. G. H. Hickford. 2008a. Lack association between CAST SNPs and meat tenderness in sheep. Anim. Genet. 39: 328-332.

Zhou, H. \& J. G. H. Hickford. 2008b. Allelic polymorphism of the caprine calpastatin (CAST) gene identified by PCRSSCP. Meat Sci. 79: 403-405

Zhou, H. \& J. G. H. Hickford. 2008c. Allelic variation of the bovine calpastatin (CAST) gene. Mol Cell Probes 22:129-130. 